\title{
Pengaruh Suplementasi Dl-Methionine terhadap Berat Hidup, Berat Karkas dan Konversi Pakan Ayam Broiler
}

\author{
Martha L. Amleni ${ }^{\mathrm{a}}$, Charles V. Lisnahan ${ }^{\mathrm{b}}$ dan Gerson F. Bira \\ ${ }^{a}$ Fakultas Pertanian, Universitas Timor, Kefamenanu, TTU - NTT, 85613, Indonesia, email: marthaamleni@gmail.com \\ ${ }^{b}$ Fakultas Pertanian, Universitas Timor, Kefamenanu, TTU - NTT, 85613, Indonesia, email: charleslisnahan@yahoo.co.id \\ ${ }^{c}$ Fakultas Pertanian, Universitas Timor, Kefamenanu, TTU - NTT, 85613, Indonesia, email: gersonbira@yahoo.co.id
}

\section{Article Info}

Article history:

Received 23 Juni 2020 Accepted 05 Oktober 2020

DOI:

https://doi.org/10.32938/ja.v5i4.1056

Keywords:

Ayam broiler

Dl-methionine

Berat hidup

Karkas

Konversi pakan
Received in revised form 10 September 2020

\section{Abstrak}

Penelitian ini bertujuan untuk mengetahui pengaruh suplementasi dl-methionine dalam pakan terhadap berat hidup, berat karkas dan konversi pakan ayam broiler. Penelitian ini telah dilaksanakan di Kandang Laboratorium Program Studi Peternakan Fakultas Pertanian Universitas Timor Kefamenanu selama 7 minggu, sejak Desember 2019 sampai Januari 2020. Penelitian ini menggunakan ayam broiler berumur 14 hari, sebanyak 80 ekor. Metode yang digunakan dalam penelitian ini adalah Rancangan Acak Lengkap pola searah terdiri dari 4 perlakuan dan 4 ulangan. Perlakuan yang diberikan adalah $\mathrm{T}_{0}$ (pakan kontrol tanpa suplementasi dl-metionine), $\mathrm{T}_{1}$ (suplementasi $0,30 \% \mathrm{dl}$-methionine dalam pakan), $\mathrm{T}_{2}$ (suplementasi $0,50 \%$ dl-methionine dalam pakan), dan $\mathrm{T}_{3}$ (suplementasi $0,70 \%$ dl-methionine dalam pakan). Variabel yang diamati dalam penelitian ini adalah berat hidup, berat karkas dan konversi pakan ayam broiler. Data yang diperoleh dianalisis dengan sidik ragam dan uji duncan. Hasil penelitian menunjukkan bahwa rata-rata berat hidup perlakuan T0, T1, T2 dan T3 masing-masing adalah $1875,00 \pm 56,79 ; 2077,25 \pm 46,51 ; 2079,00 \pm 57,11 ;$ dan 2200,50 $\pm 27,74$ g/ekor. Berat karka $1287,40 \pm 46,14 ; 1457,82 \pm 27,36 ; 1484,42 \pm 45,13$ dan $1567,32 \pm 8,27$ g/ekor. Berat dada $512,63 \pm 8,60 ; 584,44 \pm 14,27 ; 598,16 \pm 13,93$ dan

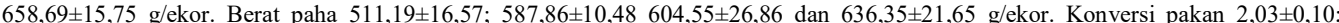
$1,70 \pm 0,07 ; 1,66 \pm 0,05$ dan $1,55 \pm 0,02$. Analisis statistik menunjukkan bahwa perlakuan berpengaruh nyata terhadap variabel yang diamati $(\mathrm{P}<0,05)$. Disimpulkan bahwa suplementasi $d l$-methionine sebesar $0,70 \%$ dalam pakan meningkatkan berat hidup, karkas dan konversi pakan ayam broiler.

\section{Pendahuluan}

Ayam broiler merupakan tipe ayam pedaging yang memiliki kemampuan berproduksi dengan kurun waktu yang singkat. Ayam broiler pada umumnya dipanen pada umur 5-7 minggu dengan berat badan mencapai $2 \mathrm{~kg}$. Salah satu faktor utama yang mempengaruhi pertumbuhan ayam broiler adalah pakan Pakan yang tersusun dari beberapa bahan pakan dengan memperhatikan keseimbangan nutrient adalah faktor yang penting untuk pertumbuhan ayam broiler tersebut. Adeyemo (2012) menyatakan bahwa ayam broiler memiliki pertumbuhan yang lebih cepat karena potensi pakan yang seimbang.

Pakan merupakan bagian penting dalam pertumbuhan ayam broile karena ayam broiler memerlukan nutrien yang cukup untuk pertumbuhan dalam berproduksi. Pakan yang diberikan harus memiliki kualitas, kuantitas dan kontinuitas yang baik. Tujuan pemberian pakan untuk ternak ayam untuk memenuhi kebutuhan pokok dan produksi. Salah satu nutrien yang penting adalah protein dengan keseimbangan asam-asam aminonya. Asam amino dapa diperoleh dengan mencampur bermacam-macam bahan pakan sumber protein dan apabila masih kurang dapat ditambahkan asam amino sintesis. Asam amino untuk ternak pada umumnya dibagi atas dua yaitu asam amino esensial dan non esensial. Salah satu asam amino esensial yang sangat penting namun tidak diproduksi oleh tubuh ternak dan menjadi faktor pembatas serta bersifat kritis bagi pertkembangan ayam broiler adalah asam amino methionine.

Methionine adalah asam amino yang biasanya dimanfaatkan pada proses biosintesis protein. Methionine merupakan asam amino esensial yang metabolitnya digunakan dalam proses biologis fundamental seperti deposis protein dan respon imunitas (Eklund et al., 2009). Selain itu, methionine berfungsi sebagai donor gugus metil $\left(\mathrm{CH}_{3}\right)$ dan menghasilkan S-adenosi methionine (Ratriyanto et al., 2009). Pemberian methionine perlu memperhatikan tingkat protein,bentuk fisik dan palatabilitas bahan pakan. Selain itu karena methionine diketahui sebagai asam amino yang bersifat racun bila berlebihan sehingga pemberiannya harus diperhatikan dengan baik Methionine juga dikenal untuk mengurangi stres oksidatif dalam tubuh dengan meningkatkan senyawa antioksidan seperti glutathione. Pada daerah tropis seperti Indonesia, umumnya ayam broiler mengalami stres panas (heat stress) karena temperatur harian yang lebih dari $24^{\circ} \mathrm{C}$. Salah satu cara mengurang stress tersebut dengan meningkatkan methionine dalam pakan yang dikonsums ayam broiler. Kelebihan lain dari methionine adalah memperkuat kondisi tubuh, mampu memperbaiki pertumbuhan dan meningkatkan bobot badan.

Dewasa ini asam amino methionine sintetis telah diproduksi untuk melengkapi pakan yang diberikan pada ternak ayam. Hal ini karena umumnya pakan yang berbasis jagung dan bungkil kedelai defisien akan asam amino methionine. Produk asam amino methionine yang ada di pasaran dalam bentuk $d$-methionine dan dl-methionine yang dijual dengan harga yang murah. Penambahan $d l$-methionine pada pakan dapat meningkatkan pertumbuhan dan efesiensi pakan (menekan konversi pakan) ayam broiler dan berkorelasi dengan efisiensi produksi. Konversi pakan dapat dilihat dengan membandingkan jumlah pakan yang dikonsumsi dengan pertambahan bobot badan dalam jangka waktu tertentu. Salah satu ukuran yang dapat digunakan dalam menilai efisiens penggunaan pakan adalah melihat bobot badannya. Peningkatan bobot badan akan berdampak pula pada karkas yang dihasilkan. Tujuan dari penelitian in adalah untuk mengetahui pengaruh suplementasi dl-methionine dalam pakan terhadap berat hidup, berat karkas dan konversi pakan ayam broiler.

\section{Metode}

\subsection{Waktu dan Tempat Penelitian}

Penelitian ini telah dilaksanakan di Kandang Program Studi Peternakan, Fakultas Pertanian Universitas Timor, Kelurahan Sasi, Kecamatan Kota
Kefamenanu, Kabupaten Timor Tengah Utara. Penelitian ini berlangsung selama 7 minggu dari bulan Desember 2019 sampai Januari 2020.

\subsection{Materi Penelitian}

Ternak

Ternak yang digunakan adalah ayam pedaging (broiler) berumur 14 hari produksi PT. Wonokoyo Surabaya sebanyak 80 ekor.

\section{Pakan dan air minum}

Pakan yang digunakan dalam penelitian ini adalah pakan BR1, $d l$ methionine dan air minum. Komposisi nutrient pakan BR1 disajikan pada Tabel 1.

Tabel 1. Komposisi nutrient pakan BR1

\begin{tabular}{lc}
\hline \multicolumn{1}{c}{ Nutrien } & BR1* \\
\hline Air (\%) & Max $12.0 \%$ \\
Protein Kasar (\%) & $20.0-22.0 \%$ \\
Lemak Kasar (\%) & Min $5.0 \%$ \\
Serat Kasar (\%) & Max $5.0 \%$ \\
Abu (\%) & Max $7.5 \%$ \\
Calcium (\%) & Min $0,9 \%$ \\
Phosphor $(\%)$ & Min $0.6 \%$ \\
Sumber: PT. Charoen pokphand, 2014. *tersusun dari jagung, katul, pollard, CGM,
\end{tabular}

$D D G S$, bungkil kedelai, tepung jagung, tulang CPO, canola, vitamin dan miniral.

\section{Kandang dan Peralatan}

Kandang yang digunakan dalam penelitian ini adalah kandang litte berukuran $7 \times 3,5$ dan tinggi atap $3 \mathrm{~m}$. Didalam kandang tersebut dibuat 16 uni kandang dengan ukuran $0,8 \times 0,7 \mathrm{~m}$. Dinding unit kandang terbuat dari kawat. Peralatan yang digunakan adalah tempat pakan 16 buah, tempat minum 16 buah, lampu pijar, timbangan merek ideal life dan ohause dengan kepekaan $1 \mathrm{~g}$ dan $0,1 \mathrm{~g}$, dan peralatan kebersihan kandang seperti sekop, sapu dan ember

\subsection{Metode Penelitian}

Metode yang akan digunakan dalam penelitian ini adalah metode eksperimen dengan Rancangan Acak Lengkap (RAL) pola searah terdiri dari 4 perlakuan dan 4 ulangan. Perlakuan yang diuji adalah :

T0 : Pakan kontrol

$\mathrm{T} 2:$ Pakan kontrol + dl-methionine $0,50 \%$

$\mathrm{T} 3$ : Pakan kontrol + dl-methionine $0,70 \%$

\subsection{Prosedur Penelitian}

Beberapa tahap yang dilakukan dalam penelitian ini adalah:

1. Persiapan kandang.

2. Seluruh ruang kandang dicucihamakan dengan antiseptik.

3. Peralatan makan dan minum dibersihkan dan dicucihamakan dengan neoantiseptik

4. Persiapan bahan kandang seperti alas kandang (sekam dan kapur)

5. Setelah DOC tiba tindakan selanjutnya adalah:

a) DOC diistirahatkan $\pm 1 / 2$ jam.

b) Pemberian air gula.

c) Pemberian pakan awal yang diberikan di tempat makan yang telah disiapkan. Pemberian air minum dicampur dengan vitamin.

6. Pada umur 3 hari dilakukan vaksinasi ND1 melalui tetes mata.

7. Pemberian pakan dan air minum yang dicampur dengan vitamin hingga ayam berumur 114 hari.
Sumber: PT. Charoen pokphand, 2014.*tersusun dari jagung, katul, pollard,

T1 : Pakan kontrol + dl-methionine $0,30 \%$ 
8. Pada umur 14 hari penempatan ayam di dalam kandang dilakukan secara acak sesuai perlakuan.

9. Adaptasi pakan sesuai perlakuan pada hari ke 114 sampai 16.

10. Pemberian perlakuan pada hari pertama sampe panen pada hari ke 17 sampai selesai.

11. Pada umur 21 hari diberikan vaksin ND2.

12. Pengambilan data selama penelitian berlangsung dan juga pada akhirpenelitian.

\subsection{Variabel Penelitian}

Berat hidup (g/ekor) pengukuran berat hidup dilakukan pada umur minggu terakhir, yang diambil secara acak dari setiap unit percobaan kemudian dilakukan penimbangan yaitu bobot ayam yang ditimbang sebelum pemotongan setelah ayam dipuasakan selama \pm 12 jam, sebagai berat hidup akhir pemeliharaan.

Berat karkas (g/ekor). Karkas ayam didefenisikan sebagai bagian tubuh ayam yang telah disembelih, dicabut bulu, dikeluarkan isi rongga perut dan dibersihkan tanpa bagian kepala, leher dan kaki. Berat karkas diukur dengan menimbang berat ayam broiler tanpa bulu, darah, kepala, dan organ dalam. Persentase karkas dapat diketahui dengan membandingkan berat karkas (g) dengan berat hidup (g) kemudian dikalikan $100 \%$.

Persentase berat karkas $(\%)=\frac{\text { Berat karkas }(\mathrm{g})}{\text { Berat hidup (g) }} \times 100 \%$

Berat dada (g/ekor). Berat dada diperoleh dengan menimbang dada seutuhnya dan untuk mendapatkan persentasenya dibandingkan dengan berat dada $(\mathrm{g})$ dengan berat hidup $(\mathrm{g})$ dikalikan $100 \%$.

\section{Persentase Berat Dada (\%) $=\frac{\text { Berat dada }(\mathrm{g})}{\text { Berat hidup (g) }} \times 100 \%$}

Berat paha (g/ekor). Berat paha diperoleh dengan cara menimbang bagian karkas yang diambil pada daerah persendian tulang paha bawah hingga pinggul (g). Persentasenya dapat diketahui dengan membandingkan berat paha atas dibagi dengan bobot hidup (g) dikalikan $100 \%$.

$$
\text { Persentase Berat Paha (\%) }=\frac{\text { Berat paha }(\mathrm{g})}{\text { Berat hidup (g) }} \times 100 \%
$$

Konversi pakan adalah perbandingan jumlah konsumsi pakan pada satu minggu dengan pertambahan bobot badan yang dicapai pada minggu itu, bila rasio kecil berarti pertambahan bobot badan ayam memuaskan atau ayam mengkonsumsi pakan secara efisien.

$$
\text { Konversi Pakan }=\frac{\text { Konsumsi pakan }(\mathrm{g})}{\text { Pertambahan berat badan }(\mathrm{g})}
$$

\subsection{Analisis Data}

Data yang diperoleh dianalisis menggunakan analisis variansi (Analysis of Variance) dan dilanjutkan dengan uji jarak berganda duncan (Duncan's New Multiple Range Test) berdasarkan Steel dan Torrie (1995). Rumus yang digunakan adalah sebagi berikut:

Yij $=\mu+\tau i+\varepsilon i j$

Keterangan :

$\begin{array}{ll}\text { Yij } & : \text { Pengamatan Perlakuan ke-I dan ulangan ke-j } \\ \mu & : \text { Rata-rata umum } \\ \tau \text { i } & : \text { Pengaruh perlakuan ke-i } \\ \varepsilon \text { ij } & : \text { Galat perlakuan ke-I dan ulangan ke-j. }\end{array}$

\section{Hasil dan Pembahasan}

\subsection{Pengaruh Perlakuan Terhadap Berat Hidup Ayam Broiler}

Berat hidup ayam broiler adalah berat badan akhir pemeliharaan sebelum dilakukan pemotongan. Rataan berat hidup ayam broiler setelah disuplementasi dl-methionine dalam pakan dapat dilihat pada Tabel 2.

Tabel 2. Rata-rata berat hidup ayam broiler (g/ekor)

\begin{tabular}{ccccc}
\hline \multirow{2}{*}{ Ulangan } & \multicolumn{4}{c}{ Perlakuan } \\
\cline { 2 - 5 } & $\mathrm{T}_{0}$ & $\mathrm{~T}_{1}$ & $\mathrm{~T}_{2}$ & $\mathrm{~T}_{3}$ \\
\hline 1 & 1857,00 & 2046,00 & 2059,00 & 2219,00 \\
2 & 1860,00 & 2041,00 & 2076,00 & 2218,00 \\
3 & 1826,00 & 2080,00 & 2158,00 & 2160,00 \\
4 & 1957,00 & 2142,00 & 2023,00 & 2205,00 \\
Jumlah & 7500,00 & 8309,00 & 8316,00 & 8802,00 \\
Rataan & $1875,00 \pm 56,79^{\mathrm{c}}$ & $2077,25 \pm 46,51^{\mathrm{b}}$ & $2079,00 \pm 57,11^{\mathrm{b}}$ & $2200,50 \pm 27,74^{\mathrm{a}}$ \\
\hline \multicolumn{2}{c}{ a, b, c superskrip pada baris yang sama menunjukkan perbedaan yang nyata $(P<0,05)}$.
\end{tabular}

Rataan berat hidup tertinggi terdapat pada perlakuan $\mathrm{T}_{3}(2200,50 \pm 27,74$ g/ekor), selanjutnya diikuti perlakuan $T_{2} \quad(2079,00 \pm 57,11$ g/ekor $), T_{1}$ $(2077,25 \pm 46,51 \mathrm{~g} /$ ekor $)$ dan terendah pada perlakuan $\mathrm{T}_{0}(1875,00 \pm 56,79$ $\mathrm{g}$ /ekor). Analisis sidik ragam menunjukkan bahwa perlakuan berpengaruh nyata terhadap berat badan ayam broiler $(\mathrm{P}<0,05)$. Semakin tinggi level dl-methionine dalam pakan semakin tinggi pula berat hidup ayam broiler. Uji Duncan menunjukkan bahwa perlakuan $T_{3}$ berbeda dengan perlakuan $T_{2}, T_{1}$ dan $T_{0}$, sedangkan perlakuan $T_{2}$ tidak berbeda dengan $T_{1}$ namun berbeda dengan $T_{0}$. Suplementasi $0,30 \%$ dl-methionine dalam pakan $\left(\mathrm{T}_{1}\right)$ meningkatkan berat badan sebesar 10,79\% dibandingkan dengan pakan tanpa penambahan dl-methionine $\left(\mathrm{T}_{0}\right)$. Pada suplementasi $0,50 \%$ dl-methionine $\left(\mathrm{T}_{2}\right)$, berat badan belum signifikan dibandingkan dengan $\mathrm{T}_{1}$, tetapi jika ditingkatkan menjadi $0,70 \% \mathrm{dl}$ methionine $\left(\mathrm{T}_{3}\right)$, berat badan meningkat secara signifikan sebesar 5,93\% dibandingkan dengan $\mathrm{T}_{1}$

Suplementasi dl-methionine memacu pertumbuhan ayam broiler. Asam amino $d l$-methionine memiliki peranan yang sangat penting bagi pertumbuhan dan perkembangan ayam broiler. Asam amino dl-methionine merupakan asam amino esensial yang digunakan dalam proses biologis fundamental seperti deposisi protein dan respon imunitas (Lisnahan et al., 2017). Asam amino $d l$ methionine merupakan asam amino yang mengandung sulfur, berfungsi sebagai donor gugus metil $\left(\mathrm{CH}_{3}\right)$ dan menghasilkan $\mathrm{S}$-adenosil methionine (Ratriyanto et al., 2009). Suplementasi dl-methionine $0,30 \%, 0,50 \%$ dan $0,70 \%$ masih dikategorikan cukup untuk meningkatkan berat hidup ayam broiler karena jika diberikan lebih kemungkinan tidak akan meningkatkan berat hidup bahkan dapat bersifat racun. dl-methionine diketahui sebagai asam amino yang bersifat racun bila diberikan secara berlebihan. Kelebihan pemberiannya akan berakibat buruk pada pertambahan berat badan. Leesson dan Summers (2001) menyatakan bahwa asam amino dl-methionine akan bersifat racun apabila diberikan dua kali lebih banyak dari kebutuhan. Hasil yang diperoleh dari penelitian ini turut didukung oleh Aisjah et al. (2007) yang menyimpulkan bahwa suplementasi methinonine sintetis $0,08 \%$ dan $0,12 \%$ (setara dengan $0,392 \%$ dan $0,432 \%$ ) memberi pengaruh yang nyata dalam meningkatkan pertambahan berat badan dan nilai imbangan efisiensi protein dibandingkan dengan suplementasi methionine sintesis $0,04 \%$ pada pakan. Dilanjutkan oleh Lisnahan et al. (2018) bahwa suplementasi dl-methionine sebesar $0,19 \%$ dan $l$ lysine $\mathrm{HCl} 0,42 \%$ pada pakan standar kafetaria dengan kandungan protein $13,20 \%$ meningkatkan kinerja berat badan ayam kampung pada umur 20 minggu. Suplementasi dl-methionine memberikan nutrien lengkap yang dapat mempercepat pertumbuhan ayam broiler karena asam amino esensial seperti methionine berperan dalam pertumbuhan jaringan tubuh ayam.

\subsection{Pengaruh Perlakuan Terhadap Konversi Pakan Ayam Broiler}

Konversi pakan atau Feed Conversion Ratio (FCR) adalah perbandingan antara jumlah konsumsi pakan dan pertambahan berat badan atau dinyatakan sebagai efesiensi pakan yaitu perbandingan bobot badan per unit konsums pakan. Nilai terendah dalam konversi pakan menunjukkan efisiensi pakan semakin baik. Rataan konversi pakan ayam broiler terlihat pada Tabel 3.

$\underline{\text { Tabel 3. Rata-rata konversi pakan ayam broiler }}$

\begin{tabular}{ccccc}
\hline \multirow{2}{*}{ Ulangan } & \multicolumn{4}{c}{ Perlakuan } \\
\cline { 2 - 5 } & $\mathrm{T}_{0}$ & $\mathrm{~T}_{1}$ & $\mathrm{~T}_{2}$ & $\mathrm{~T}_{3}$ \\
\hline 1 & 2,03 & 1,73 & 1,67 & 1,54 \\
2 & 2,07 & 1,77 & 1,63 & 1,54 \\
3 & 2,13 & 1,67 & 1,60 & 1,57 \\
4 & 1,90 & 1,62 & 1,72 & 1,54 \\
Jumlah & 8,12 & 6,79 & 6,63 & 6,19 \\
Rata-rata & $2,03 \pm 0,10^{\mathrm{a}}$ & $1,70 \pm 0,07^{\mathrm{b}}$ & $1,66 \pm 0,05^{\mathrm{b}}$ & $1,55 \pm 0,02^{\mathrm{c}}$ \\
\hline
\end{tabular}

$a, b, c$ superskrip pada baris yang sama menunjukkan perbedaan yang nyata $(P<0,05)$.

Rataan konversi pakan tertinggi terdapat pada perlakuan $\mathrm{T}_{0}$ yaitu $2,03 \pm 0,10$. Selanjutnya diikuti perlakuan $T_{1}(1,70 \pm 0,07), T_{2}(1,66 \pm 0,05)$ dan terendah pada perlakuan $\mathrm{T}_{3}(1,55 \pm 0,02)$. Analisis sidik ragam menunjukkan bahwa perlakuan berpengaruh nyata terhadap konversi pakan ayam broiler $(\mathrm{P}<0,05)$. Semakin meningkat level dl-methionine dalam pakan maka konversi pakan semakin menurun atau meningkatkan efisiensi pakan ayam broiler. Hal ini menunjukkan bahwa semakin meningkatnya suplementasi dl-methionine maka semakin efisien dalam menghasilkan berat badan. Uji duncan menunjukkan bahwa konversi pakan terbaik pada perlakuan $\mathrm{T}_{3}$ dibandingkan dengan $T_{2}, T_{1}$ dan $T_{0}$. Perlakuan $T_{1}$ dan $T_{2}$ memberikan respon yang sama dan lebih baik dibandingkan dengan $\mathrm{T}_{0}$. Hal ini menunjukkan bahwa suplementasi dl-methionine sebanyak $0,70 \%$ menghasilkan konversi pakan terbaik.

Suplementasi $0,30 \%$ dl-methionine dalam pakan $\left(\mathrm{T}_{1}\right)$ menekan konversi pakan sebesar $16,36 \%$ dibandingkan dengan $\mathrm{T}_{0}$. Suplementasi $0,50 \% \mathrm{dl}$ methionine $\left(\mathrm{T}_{2}\right)$ memberikan respon yang sama dengan $T_{1}$, tetapi jika ditingkatkan lagi menjadi $0,70 \%$ dl-methionine, konversi pakan masih dapat ditekan sebesar $8,86 \%$. Konversi pakan digunakan untuk mengukur produktivitas ternak dan didefinisikan sebagai rasio antara konsumsi pakan dengan pertambahan bobot badan yang diperoleh selama kurun waktu tertentu (Lacy dan Vest, 2000). Efisiensi penggunaan pakan dapat dilihat dari nilai konversi pakan yang diberikan. Konversi pakan yang semakin kecil merupakan indikator semakin tingginya efisiensi pakan. Sebaliknya, konversi pakan yang semakin besar merupakan indikator semakin rendahnya efisiensi pakan.

Pada umumnya konversi pakan dipengaruhi oleh genetik, tipe pakan yang digunakan, feed additive yang digunakan dalam pakan, manajemen pemeliharaan, dan suhu lingkungan (James, 2004). Salah satu produk sintetis asam amino methionine adalah dl-methionine. Dl-methionine mempunyai daya serap 99\%. Dl-methionine yang dikonsumsi langsung diserap melalui vili usus kedalam seluruh jaringan tubuh. Didalam mitokondria, methionine bersama dengan asam amino lainnya membentuk protein jaringan tubuh. Pada umumnya pakan ternak ayam berbasis jagung dan bungkil kedelai selalu defisien asam amino esensial seperti methionine dan lysine sehingga bila dilakukan penambahan asam amino tersebut ke dalam pakan dapat memperbaiki kualitas pakan (Soeharto, 1980). Jika kualitas pakan meningkat maka meningkatkan berat badan 
Konversi pakan yang dihasilkan dari penelitian ini (diluar kontrol) lebih baik jika dibandingkan dengan laporan Bintang et al. (2005) yaitu 1,79-1,82 pada ayam broiler yang diberikan pakan dengan penambahan $\beta$-Xilanase dan $\beta$ Glukanase. Konversi pakan ayam broiler yang diberikan campuran probiotik dan prebiotic sebesar 2,11-2,16 (Daud, 2005). Hal ini jelas menggambarkan bahwa dl-methionine sangat esensial dibutuhkan oleh ayam broiler untuk pertumbuhan dan perkembangannya. Wiradisastra (2001) menyatakan bahwa tingkat methionine dalam pakan sebesar 0,392 dan $0,432 \%$ memberi pengaruh yang sangat nyata meningkatkan pertambahan berat badan dan menurunkan konversi pakan. Hal ini menunjukkan bahwa suplementasi sebanyak $0,70 \%$ dalam penelitian ini masih dapat ditolerir yang terlihat dari nilai konversi pakan dan berat hidup ayam broiler.

\subsection{Pengaruh Perlakuan Terhadap Berat Karkas Ayam Broiler}

Karkas ayam broiler adalah bagian tubuh ayam yang disembelih lalu dibuang darah, kaki bagian bawah mulai tarsus metatarsus kebawah, kepala, leher serta dicabut bulu, dan organ dalam kecuali paru-paru dan ginjal (Yao $e t$ al., 2006). Tabel 4 dan 5 merupakan berat karkas ayam broiler yang diberi pakan suplementasi dl-methionine. Rataan berat karkas tertinggi terdapat pada perlakuan $\mathrm{T}_{3}$ yaitu $1567,32 \pm 8,27 \mathrm{~g} /$ ekor atau $71,23 \pm 0,94 \%$ /ekor. Selanjutnya diikuti perlakuan $\mathrm{T}_{2}(1484,42 \pm 45,1 \mathrm{~g} /$ ekor atau $71,40 \pm 0,33 \%$ /ekor $), \mathrm{T}_{1}$ $\left(1457,82 \pm 27 \mathrm{~g} /\right.$ ekor atau $70,18 \pm 0,33 \%$ /ekor) dan terendah pada perlakuan $\mathrm{T}_{0}$ $(1287,40 \pm 46 \mathrm{~g} /$ ekor atau $68,66 \pm 1,11 \% /$ ekor).

Tabel 4. Rata-rata berat karkas ayam broiler (g/ekor)

\begin{tabular}{ccccc}
\hline \multirow{2}{*}{ Ulangan } & \multicolumn{4}{c}{ Perlakuan } \\
\cline { 2 - 5 } & $\mathrm{T}_{0}$ & $\mathrm{~T}_{1}$ & $\mathrm{~T}_{2}$ & $\mathrm{~T}_{3}$ \\
\hline 1 & 1244,76 & 1437,46 & 1462,4 & 1559,15 \\
2 & 1292,8 & 1435,05 & 1479,51 & 1578,82 \\
3 & 1262,17 & 1465,54 & 1549,06 & 1566,24 \\
4 & 1349,88 & 1493,21 & 1446,69 & 1565,07 \\
Jumlah & 5149,61 & 5831,26 & 5937,66 & 6269,28 \\
Rataan & $1287,40 \pm 46,14^{\mathrm{c}}$ & $1457,82 \pm 27,36^{\mathrm{b}}$ & $1484,42 \pm 45,13^{\mathrm{b}}$ & $1567,32 \pm 8,27^{\mathrm{a}}$ \\
\hline
\end{tabular}

$a, b, c$ superskrip pada baris yang sama menunjukkan perbedaan yang nyata $(P<0,05)$.

Tabel 5. Rata-rata persentase karkas ayam broiler (\%)

\begin{tabular}{ccccc}
\hline \multirow{2}{*}{ Ulangan } & \multicolumn{4}{c}{ Perlakuan } \\
\cline { 2 - 5 } & $\mathrm{T}_{0}$ & $\mathrm{~T}_{1}$ & $\mathrm{~T}_{2}$ & $\mathrm{~T}_{3}$ \\
\hline 1 & 67,03 & 70,26 & 71,02 & 70,26 \\
2 & 69,51 & 70,31 & 71,27 & 71,18 \\
3 & 69,12 & 70,46 & 71,78 & 72,51 \\
4 & 68,98 & 69,71 & 71,51 & 70,98 \\
Jumlah & 274,64 & 280,74 & 285,59 & 284,94 \\
Rata-rata & $68,66 \pm 1,11^{\mathrm{b}}$ & $70,18 \pm 0,33^{\mathrm{a}}$ & $71,40 \pm 0,33^{\mathrm{a}}$ & $71,23 \pm 0,94^{\mathrm{a}}$ \\
\hline a, b superskrip pada baris yang sama menunjukkan perbedaan yang nyata $(P<0,05)$
\end{tabular}

Analisis sidik ragam menunjukkan bahwa perlakuan berpengaruh nyata terhadap berat karkas ayam broiler $(\mathrm{P}<0,05)$. Semakin meningkat level $\mathrm{dl}$ methionine dalam pakan semakin tinggi pula berat karkas ayam broiler yang dihasilkan. Uji Duncan menunjukkan bahwa perlakuan $\mathrm{T}_{3}$ lebih baik dibandingkan dengan $T_{2}, T_{1}$ dan $T_{0}$, sedangkan $T_{2}$ dan $T_{1}$ lebih baik dari $T_{0}$. Suplementasi $0,30 \%$ dl-methionine dalam pakan $\left(\mathrm{T}_{1}\right)$ meningkatkan berat karkas sebesar $13,24 \%$ dibandingkan dengan pakan tanpa penambahan $\mathrm{dl}$ methionine $\left(\mathrm{T}_{0}\right)$. Pada suplementasi $0,50 \%$ dl-methionine $\left(\mathrm{T}_{2}\right)$, berat karkas belum signifikan dibandingkan dengan $\mathrm{T}_{1}$, tetapi jika ditingkatkan menjadi $0,70 \%$ dl-methionine $\left(\mathrm{T}_{3}\right)$, berat badan meningkat secara signifikan sebesar $7,51 \%$ dibandingkan dengan $\mathrm{T}_{1}$.

Penilaian karkas ternak didasarkan pada berat karkas dan tingkat perlemakan tubuh. Dari Tabel 4 dan 5 menghasilkan berat karkas yang cukup tinggi dari kontrol. Hal ini memberi gambaran bahwa suplementasi asam amino dl-methionine sangat mempengaruhi karkas yang dihasilkan. Suplementasi $d l$ methionine memberikan nutrien lebih lengkap yang dapat mempengaruhi dan mempercepat pertumbuhan jaringan tubuh ayam yang terlihat dari karkas yang dihasilkan. Hasil ini sama dengan yang dilaporkan Lisnahan et al. (2017) melalui penambahan methionine dan lysine dalam pakan sebagai prekursor karnitin. Hal ini menunjukkan betapa pentingya penambahan dl-methionine dalam pakan untuk meningkatkan performans ayam broiler. Bunchasak et al. (2006) melaporkan bahwa broiler yang disuplementasi dl-methionine mempunyai PBB yang lebih tinggi dibandingkan dengan broiler yang diberi pakan basal tanpa dl-methionine dan hal ini berdampak pada karkas yang dihasilkan. Tujuan utama dari pemeliharaan ayam broiler adalah menghasilkan daging atau karkas yang tinggi. Semakin tinggi suplementasi dl-methionine, meningkatkan berat hidup dan berat hidup ini berdampak pada berat karkas yang dihasilkan.

\subsection{Pengaruh Perlakuan Terhadap Berat Dada Ayam Broiler}

Dada merupakan bagian potongan komersial yang paling banyak mengandung daging. Rata-rata berat dada ayam broiler yang diberi pakan dengan suplementasi dl-methionine terlihat pada Tabel 6 dan 7. Rata-rata berat dada tertinggi terdapat pada perlakuan $\mathrm{T}_{3}$ yaitu $658,69 \pm 15,75 \mathrm{~g} / \mathrm{ekor}$ atau $29,93 \pm 0,39 \% /$ ekor, selanjutnya diikuti perlakuan $\mathrm{T}_{2}$ sebesar $598,16 \pm 13,93$ g/ekor atau $28,77 \pm 0,22 \%$ /ekor, $\mathrm{T}_{1}$ sebesar $584,44 \pm 14,27$ g/ekor atau $28,13 \pm 0,13 \% /$ ekor dan terendah pada perlakuan $\mathrm{T}_{0}$ yaitu $512,63 \pm 8,60 \mathrm{~g}$ /ekor atau $27,35 \pm 0,42 \% /$ ekor. Analisis sidik ragam menunjukkan bahwa perlakuan berpengaruh nyata terhadap berat dada ayam broiler $(P<0,05)$. Semakin tinggi level dl-methionine dalam pakan semakin tinggi pula berat dada ayam broiler Uji Duncan menunjukkan bahwa perlakuan $\mathrm{T}_{3}$ lebihbaikdibandingkandengan $\mathrm{T}_{2}$, $\mathrm{T}_{1}$ dan $\mathrm{T}_{0}$, sedangkan $\mathrm{T}_{2}$ dan $\mathrm{T}_{1}$ lebih baik dari $\mathrm{T}_{0}$.

Suplementasi $0,30 \%$ dl-methionine dalam pakan $\left(\mathrm{T}_{1}\right)$ meningkatkan berat badan sebesar $12,28 \%$ dibandingkan dengan pakan tanpa penambahan $d l-$ methionine $\left(\mathrm{T}_{0}\right)$. Pada suplementasi $0,50 \%$ dl-methionine $\left(\mathrm{T}_{2}\right)$, berat badan belum signifikan dibandingkan dengan $\mathrm{T}_{1}$, tetapi jika ditingkatkan menjadi $0,70 \%$ dl-methionine $\left(\mathrm{T}_{3}\right)$, berat dada meningkat secara signifikan sebesar $11,27 \%$ dibandingkan dengan $T_{1}$.

$\underline{\text { Tabel 6. Rata-rata berat dada ayam broiler (g/ekor) }}$

\begin{tabular}{ccccc}
\hline \multirow{2}{*}{ Ulangan } & \multicolumn{4}{c}{ Perlakuan } \\
\cline { 2 - 5 } & $\mathrm{T}_{0}$ & $\mathrm{~T}_{1}$ & $\mathrm{~T}_{2}$ & $\mathrm{~T}_{3}$ \\
\hline 1 & 513,47 & 573,89 & 595,43 & 675,69 \\
2 & 506,60 & 572,35 & 592,26 & 665,84 \\
3 & 505,97 & 588,79 & 618,33 & 639,11 \\
4 & 524,48 & 602,72 & 586,61 & 654,11 \\
Jumlah & 2050,52 & 2337,75 & 2392,63 & 2634,75 \\
Rataan & $512,63 \pm 8,60^{\mathrm{c}}$ & $584,44 \pm 14,27^{\mathrm{b}}$ & $598,16 \pm 13,93^{\mathrm{b}}$ & $658,69 \pm 15,75^{\mathrm{a}}$ \\
\hline a, b, c superskrip pada baris yang sama menunjukkan perbedaan yang nyata $(P<0,05)$
\end{tabular}

Tabel 7. Rata-rata persentase dada ayam broiler (\%)

\begin{tabular}{ccccc}
\hline \multirow{2}{*}{ Ulangan } & \multicolumn{4}{c}{ Perlakuan } \\
\cline { 2 - 5 } & $\mathrm{T}_{0}$ & $\mathrm{~T}_{1}$ & $\mathrm{~T}_{2}$ & $\mathrm{~T}_{3}$ \\
\hline 1 & 27,65 & 28,05 & 28,92 & 30,45 \\
2 & 27,24 & 28,04 & 28,53 & 30,02 \\
3 & 27,71 & 28,31 & 28,65 & 29,59 \\
4 & 26,80 & 28,14 & 29,00 & 29,66 \\
Jumlah & 109,40 & 112,54 & 115,10 & 119,72 \\
Rata-rata & $27,35 \pm 0,42$ & $28,13 \pm 0,13$ & $28,77 \pm 0,22$ & $29,93 \pm 0,39$ \\
\hline$a, b, c$, d superskrip pada baris yang sama menunjukkan perbedaan yang nyata $(P<0,05)$
\end{tabular}

Pada dasarnya dada merupakan bagian dari karkas ayam yang memiliki daging terbanyak. Rata-rata berat dada ayam broiler yang diberi perlakuan suplementasi dl-methionine lebih tinggi dari tanpa suplementasi. Berat dada yang tinggi dari semua perlakuan $\left(T_{1}, T_{2}\right.$ dan $\left.T_{3}\right)$ menunjukkan bahwa suplementasi dl-methionine sangat efisien untuk meningkatkan pertumbuhan dan perkembangan ayam broiler. Pertumbuhan ayam broiler secara sederhana dilihat dari berat hidup, berat karkas maupun berat potongan karkas termasuk berat dada. Wiradisastra (2001) menyatakan bahwa pembentukan daging bagian dada pada ayam broiler sangat sensitif dipengaruhi oleh metionine dalam pakannya. Ada hubungan yang erat antara berat karkas dengan komponen tubuh. Selama masa pertumbuhan, tulang bertumbuh secara kontinyu dengan laju pertumbuhan yang relatif cepat sedangkan otot relatif lambat kemudian menjadi cepat pada fase grower (Soeparno, 1992).

\subsection{Pengaruh Perlakuan Terhadap Berat Paha Ayam Broiler}

Rata-rata berat paha dan persentase berat paha ayam broiler disajikan pada Tabel 8 dan 9. Rata-rata berat paha tertinggi terdapat pada perlakuan $\mathrm{T}_{3}$ yaitu $636,35 \pm 21,65 \mathrm{~g} /$ ekor atau $28,91 \pm 0,74 \%$ /ekor, selanjutnya diikuti perlakuan $\mathrm{T}_{2}$ sebesar $604,55 \pm 26$ g/ekor atau $29,07 \pm 0,57 \%$ /ekor, $\mathrm{T}_{1}$ sebesar $587,86 \pm 10,48 \mathrm{~g}$ /ekor atau $28,30 \pm 0,49 \%$ /ekor dan terendah pada perlakuan $\mathrm{T}_{0}$ yakni $511,19 \pm 16,57 \mathrm{~g} /$ ekor atau $27,26 \pm 0,47 \%$ /ekor. Analisis sidik ragam menunjukkan bahwa perlakuan berpengaruh nyata $(\mathrm{P}<0,05)$ terhadap berat paha ayam broiler. Semakin tinggi level dl-methionine dalam pakan semakin tinggi pula berat paha ayam broiler yang dihasilkan. Uji duncan menunjukkan bahwa perlakuan $T_{3}$ lebih baik dibandingkan dengan $T_{2}, T_{1}$ dan $T_{0}, T_{2}$ dan $T_{1}$ lebih baik dari $\mathrm{T}_{0}$.

Tabel 8. Rata-rata berat paha ayam broiler (g/ekor)

\begin{tabular}{ccccc}
\hline \multirow{2}{*}{ Ulangan } & \multicolumn{4}{c}{ Perlakuan } \\
\cline { 2 - 5 } & $\mathrm{T}_{0}$ & $\mathrm{~T}_{1}$ & $\mathrm{~T}_{2}$ & $\mathrm{~T}_{3}$ \\
\hline 1 & 499,45 & 588,72 & 590,48 & 648,05 \\
2 & 519,92 & 572,81 & 613,85 & 660,92 \\
3 & 495,30 & 595,93 & 637,49 & 616,14 \\
4 & 530,08 & 593,97 & 576,36 & 620,30 \\
Jumlah & 2044,75 & 2351,43 & 2418,18 & 2545,41 \\
Rataan & $511,19 \pm 16,57^{\mathrm{c}}$ & $587,86 \pm 10,48^{\mathrm{b}}$ & $604,55 \pm 26,86^{\mathrm{b}}$ & $636,35 \pm 21,65^{\mathrm{a}}$ \\
\hline
\end{tabular}

$a, b, c$ superskrip pada baris yang sama menunjukkan perbedaan yang nyata $(P<0,05)$

Tabel 9. Rata-rata persentase paha ayam broiler (\%)

\begin{tabular}{ccccc}
\hline \multirow{2}{*}{ Ulangan } & \multicolumn{4}{c}{ Perlakuan } \\
\cline { 2 - 5 } & $\mathrm{T}_{0}$ & $\mathrm{~T}_{1}$ & $\mathrm{~T}_{2}$ & $\mathrm{~T}_{3}$ \\
\hline 1 & 26,90 & 28,77 & 28,68 & 29,20 \\
2 & 27,95 & 28,07 & 29,57 & 29,80 \\
3 & 27,12 & 28,65 & 29,54 & 28,53 \\
4 & 27,09 & 27,73 & 28,49 & 28,13 \\
Jumlah & 109,06 & 113,22 & 116,28 & 115,66 \\
Rata-rata & $27,26 \pm 0,47^{\text {a }}$ & $28,30 \pm 0,49^{\text {a }}$ & $29,07 \pm 0,57^{\text {a }}$ & $28,91 \pm 0,74^{\text {a }}$ \\
\hline a, b superskrip pada baris yang sama menunjukkan perbedaan yang nyata $(P<0,05)$
\end{tabular}


Suplementasi 0,30\% dl-methionine dalam pakan $\left(\mathrm{T}_{1}\right)$ meningkatkan berat badan sebesar $13,04 \%$ dibandingkan dengan pakan tanpa penambahan $\mathrm{dl}$ methionine $\left(\mathrm{T}_{0}\right)$. Pada suplementasi $0,50 \%$ dl-methionine $\left(\mathrm{T}_{2}\right)$, berat paha belum signifikan dibandingkan dengan $\mathrm{T}_{1}$, tetapi jika ditingkatkan menjadi $0,70 \%$ $\left(\mathrm{T}_{3}\right)$, berat badan meningkat secara signifikan sebesar $7,62 \%$ dibandingkan dengan $T_{1}$.

Paha merupakan bagian dari karkas sehingga jika berat karkasnya tinggi besar kemungkinan berat pahanya juga tinggi. Hasil penelitian ini menunjukkan bahwa berat paha ayam broiler meningkat seiring dengan meningkatnya berat karkas sebagai akibat dari suplementasi dl-methionine. Usman et al. (2016) melaporkan bahwa persentase berat paha ayam sebesar $28 \%$ pada ayam broiler yang diberikan prebiotik immuno forte dengan level berbeda. Hal ini jelas memperlihatkan bahwa asam amino sintesis seperti dl-methionine sangat penting untuk ditambahkan dalam pakan agar pertumbuhan dan perkembangan ayam broiler semakin tinggi. Methionine merupakan salah satu dari asam amino esensial, oleh karena itu harus tersedia dalam pakan dalam jumlah yang cukup, selain itu methionine merupakan asam amino pembatas utama pada pakan ayam (Wiradisastra, 2001).

\section{Simpulan}

Berdasarkan hasil dan pembahasan dapat disimpulkan bahwa suplementasi dl-methionine sebesar $0,70 \%$ dalam pakan meningkatkan berat hidup, karkas dan konversi pakan ayam broiler.

\section{Pustaka}

Adeyemo, G. O. 2012. Growth performance of broiler chickens fed fosil shell growth promoted. Departement of Animal Science, Faculty of Agriculture and Forestry, University of Ibadan, Ibadan, Nigeria. Food and Nutrition Science, 4 : 16-19.

Aisjah, T., R. Wiradimadja dan Abun. 2007. Suplementasi metionin dalam pakan berbasis lokal terhadap imbangan efisiensi protein pada ayam pedaging. Artikel Ilmiah. Jurusan Ilmu Nutrisi Dan Makanan Ternak Fakultas Peternakan Universitas Padjadjaran. Bandung.

Bintang, I.A.K., A.P. Sinurat dan T. Purwadaria. 2005. Pengaruh tingkat penggunaan bioaktif lidah buaya (Aloe vera) terhadap produksi telur ayam. Jurnal Ilmu Ternak dan Veteriner, 10 (2): 85-89.

Bunchasak, C., T. Sooksridang, and R. Chaiyapit. 2006. Effect of adding methionine hydroxyl analogue as methionine source at the commercia: requirement recommendation of production performace and evidence of ascites eyndrome of male broiler chicks fed corn-soybean based. $J$ Poult. Sci, 5 (8) : 744-752.

Daud, M. 2005. Performan ayam pedaging yang diberi probiotik dan prebiotik dalam pakan. Jurnal Ilmu Ternak, 5 (2) : 75-79.

James, G. 2004. Surgarcane. Blackwell Publishing Company. Oxford OX4 2Dq, UK. $216 \mathrm{hlm}$.

Lacy, M. dan L. R. Vest. 2000. Improving feed conversion in broiler a quide for growers.http://www.ces.uga.edu/pubed/c:793-W. html

Leesson, S. and J. D. Summers. 2001. Nutrition of the Chicken. 4th Edition. University Books. Guelph, Omtario : Canada.

Lisnahan, C.V., Wihandoyo., Zuprizal and S. Harimurti. 2017. Effect of addition of methionine and lysine into diets based of cafeteria standards on the growth performance of native chickens at starter phase. International Journal of Poultry Science, 16 (12) : 506-510.

Lisnahan, C.V., Wihandoyo., Zuprizal dan S. Harimurti. 2018. Pengaruh Suplementasi Dl-Metionin dan L-Lisin $\mathrm{HCl}$ Pada Pakan Standar Kafetaria Terhadap Berat Badan, Organ Dalam dan Organ Reproduksi Ayam Kampung Fase Pullet. Jurnal Ilmiah Peternakan Terpadu, 6 (2) : 128-133.

Eklund, M., R. Mosethin., M. Tafaj and J. Wamatu. 2009. Effects of betaine and condesed molasses solubles on nitrogen balance and nutrient digestibility in piget fed diet deficient in methionine and low in compatible osmolytes.Arch. Anim. Nutr, 60:289-300.

Ratriyanto, A., R. Mosenthin, E. Bauer, and M. Eklund. 2009. Metabolic, osmoregulatory and nutritional functions of betaine in monogastric animals. Asian-Australasian Journal of Animal Sciences, 22 (10): 14611476.

Soeharto, P.R. 1980. Protein dan Asam-Asam Amino. Poultry Indonesia. No: 28.

Soeparno. 1992. Ilmu dan Teknologi Daging. Ed. keempat. Gadjah Mada University Press. Yogyakarta.

Steel, R. G. D., dan J. H. Torrie. 1995. Prinsip dan Prosedur Statistika. Edisi ke4. Penerbit Gramedia Pustaka Utama. Jakarta.

Usman, Y., H. Latif dan J. Abdilla. 2016. Pengaruh pemberian prebiotik immuno forte dengan level berbeda terhadap berat dan persentase karkas ayam broiler. Jurnal Ilmiah Mahasiswa Pertanian Unsyiah, 1 (1) : 739745.

Wiradisastra, D.H. 2001. Pengaruh tingkat metionin dalam pakan terhadap prestasi ayam broiler umur 3 - 6 minggu. Jurnal Bionatura, 3 (1): 27-34.

Yao, J., X. Tian., H. XI., J. Han., M. Xu dan X. Wu. 2006. Feeding on performance, gastrointestinal development and feed restriction to broiler chicken production a review. Departemen of Animal Science, University of Alberta. Canada 